\title{
Analysis of Open Data Availability in Czech Republic Agrarian Sector
}

\author{
J. Jarolímek, R. Martinec \\ Faculty of Economics and Management, Czech University of Life Sciences Prague, Czech Republic
}

\begin{abstract}
In the agrarian sector several tens of billions Czech crowns of state and European aid is redistributed annually. The openness of related data and any other that can support economic stability and competitiveness of Czech agrarian sector is a challenge not only for officials but also for research and non-profit sector.

In order to determine the current state of availability of open data in agrarian sector 10 departmental institutions have been selected, which are the main producers of agricultural data in the Czech Republic, along with the CZSO (Czech Statistical Office) which is another significant source of agricultural data. The evaluation took place in the first quarter of 2016. The result is a statement that data in formats that allow further processing is published only by two out of ten surveyed departmental organizations. A similar situation prevails in the National Catalog of Open Data where there is no data coming from regarding the agricultural sector.

It is proven that making the data open can bring benefits to both farmers themselves, end consumers and other commercial entities. On the other hand, it is necessary to ensure the safety of data providers, data creators and in turn, the national security.
\end{abstract}

\section{Keywords}

Open data, agrarian sector, Ministry of Agriculture, standardization, agriculture, food industry.

Jarolímek J., and Martinec, R. (2016) "Analysis of Open Data Availability in Czech Republic Agrarian Sector", AGRIS on-line Papers in Economics and Informatics, Vol. 8, No. 3, pp. 57 - 67. ISSN 1804-1930, DOI 10.7160/aol.2016.080306.

\section{Introduction}

Open data may be, in addition to the most frequently mentioned benefits such as transparency of public administration, public awareness, etc. also very beneficial for the economy of the sector and the entire country. It opens up new economic opportunities and possibilities for further development of job offers and new services. It is important for discovering new connections and knowledge in the sector (Atenas et al., 2015). It can be used in virtually all sectors of the national economy, including agricultural enterprises (Vanek et al., 2010), (Stočes et al., 2015).

Data are holding role of an unlimited and reusable "raw material" for further processing, creating applications that generate added value, profit and new jobs. (Ministry of Interior, 2015).

The main economic benefits are as follows (Janssen et al., 2012):
- stimulating economic growth and competitiveness

- innovation stimulation

- methods of improving processes, products and services

- development of new products and services

- $\quad$ harnessing the collective wisdom

- creation of new industries

- the availability of information for investors and companies

Another benefit of data openness is also the improvement of data infrastructure in the public administration. Individual institutions will have more "order" in their data, the possibilities for data analysis will increase, and data will be cataloged. Its publication also allows better organizing and optimizing of the institutions's own internal processes (Lassinantti et al., 2014). Processes and data quality of public administration should 
improve as well. It will bring a higher level of communication and cooperation between public administration institutions. Opening up data helps to replace unnecessarily complex data exchange between different institutions (Ministry of Interior, 2015).

Open data is the path to open government. It is the next step from bureaucratic governance towards greater involvement of citizens in the management of the country. Open government should increase the overall operating efficiency of the state administration and introduce a noticeable reduction in bureaucracy, which is considered as the future of all democratic countries. One of the tools of open government are currently open data (Zuiderwijk et al., 2015). To accomplish this goal, it is necessary for all areas of government to be involved in the project. This greatly concerns the agrarian sector. It is proven that open data can bring certain benefits to farmers themselves, end consumers and also other commercial entities (Bellon-Maurel et al., 2015). On the other hand, it is necessary to further ensure the safety of both data providers, data creators and last but not least, national security. Therefore, it is necessary to follow the laws and regulations which regulate this and related issues. It is more than obvious that open data, and in turn open government has its place in the future in most areas of the national economy.

\section{Situation in the Czech Republic}

In 2014, in the rating the openness of data conducted by the nonprofit organization Open Knowledge, the Czech Republic took 13th place with a score of $66 \%$. The organization assesses the openness of data based on the following criteria:

- publishing under an open license

- machine-readability

- data cost

- bulk processability

- data freshness

- online availability

- level of digitization

- public access to data

- unavailability of similar data elsewhere.

All these criteria are met in the Czech Republic in only two areas, which are area maps and national election results. National budgets and statistics also score almost 100 percent with minor exceptions. Data being outdated and not readily available is a common problem at departmental organizations and local (municipal, city) datasets don not have finalized license agreements. Worst of all the reviews were data on government expenditure, indicating a low level of transparency in this area (Open Knowledge, 2014). The situation in the availability of agricultural data in the European Union is described by (Holster et al., 2011). In the agrarian sector several tens of billions crowns of state and European aid is annually redistributed. The openness of these data and any other that can support economic stability and competitiveness of Czech agrarian sector are a challenge not only for officials but also for researchers and non-profit sector (Hossain et al., 2016).

\section{Legislative framework}

When publishing data from state institutions it is necessary to deal with it first in terms of legislation of the State. In the world there are different approaches concerning the open data in terms of legislation. Czech Republic, like other countries of the European Union, is bound to follow the regulations and directives of the European Commission. Czech government is then obliged to integrate these regulations into Czech legislation. But the access to information by citizens is however already engraved in the Charter of Fundamental Rights and Freedoms.

The most important law on the subject in the Czech Republic is the Act no. 106/1999 Coll., on free access to information. It regulates the conditions of access to public sector information and processes directives 2003/98/ES and 2013/37/EU on the reuse of public sector information. The law obliges government institutions to publish information on their own or upon a request (Czech Republic, 1999) (European Parliament and Council, 2013).

The law was supplemented by references to the Act no. 365/2000 Coll. and the statute of obligation to provide information without requests (§4b "Provision of information disclosure") in accordance with the technical and legal standards for open data (Ministry of Interior, 2015).

Other modifications are done by the Decree of the Ministry of Interior about open data and National Open Data Catalog. It adresses:

- the significance of the data sets and their criteria

- standards for publishing open data

- technical standards for the content, structure and method of publication of the National catalog and the local catalogs of open data. 
This decree is complemented by the technical manual of open data, which was also issued by the Ministry of Interior. This manual includes the following (Ministry of Interior, 2015):

- detailed specification of individual degrees of openness introduced by the decree

- technical standards for data sets published on degrees of openness 3 and 5

- $\quad$ recommended procedure for opening data up and cataloging

- attributes of a catalog record in the National Catalog of Open Data

- technical standards for recommended data sets

- technical standards for local catalog interfaces.

Area of spatially oriented data is specifically addressed at European level by INSPIRE Directive. The directive came into force in 2007. Its part is also the basis for coordination mechanisms needed for the infrastructure at European level (Thorp and Bronson, 2013) (Kubatova and Faugnerova, n.d.). Into Czech legislation it was transported in 2009 via an amendment to Act no. 380/2009 Coll.

\section{Materials and methods}

Evaluation of data openness in agricultural sector was based on a five-star schema compiled by Tim Berners-Lee (Table 1) and the suitability of the formats used (Table 2).

\begin{tabular}{|c|c|c|}
\hline $\begin{array}{l}\text { Degree of } \\
\text { openness }\end{array}$ & Conditions & $\begin{array}{l}\text { Possible data } \\
\text { formats }\end{array}$ \\
\hline 统 & - Open data licence & PDF \\
\hline 次方 & $\begin{array}{l}\text { - Open data licence } \\
\text { - Machine readable data format }\end{array}$ & Excel \\
\hline 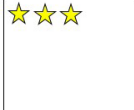 & $\begin{array}{l}\text { - Open data licence } \\
\text { - Machine readable data format } \\
\text { - Open data format }\end{array}$ & CSV, XML \\
\hline 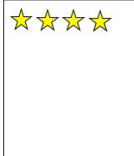 & $\begin{array}{l}\text { - } \text { Open data licence } \\
\text { - Machine readable data format } \\
\text { - Open data format } \\
\text { - Source identification using URI }\end{array}$ & $\begin{array}{l}\mathrm{RDF} \text { without } \\
\text { connection to other } \\
\text { sources }\end{array}$ \\
\hline 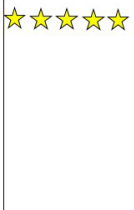 & $\begin{array}{l}\text { - Open data licence } \\
\text { - Machine readable data format } \\
\text { - Open data format } \\
\text { - Source identification using URI } \\
\text { - Links to other relevant information } \\
\text { sources }\end{array}$ & $\begin{array}{l}\text { RDF with } \\
\text { connection to other } \\
\text { sources } \\
\text { Linked Open Data }\end{array}$ \\
\hline
\end{tabular}

Source: Hausenblas (2012)

Table 1: Data openness level.

From the table 2 it is clear that the most preferred format for publication is RDF. It should however be noted that the path towards this format is still very long. A professional qualification and experience in the field as well as overall knowledge of data connectivity are necessary for its use (Gymrek and Farjoun, 2016). During the first publication of any open data the XML format which excels in simple construction, good clarity and great openness would therefore be a good choice. On its basis it is possible to build a variety of different applications. Within the geographic data GeoJSON format is often used, which is based

\begin{tabular}{|c|c|c|c|c|c|c|}
\hline Format & $\begin{array}{c}\text { Application } \\
\text { Independence }\end{array}$ & Structured & $\begin{array}{c}\text { Structure } \\
\text { Description }\end{array}$ & $\begin{array}{c}\text { Data } \\
\text { Semantics }\end{array}$ & $\begin{array}{c}\text { Creation } \\
\text { by linking }\end{array}$ & $\begin{array}{c}\text { Suit-ability } \\
1=\text { best }\end{array}$ \\
\hline PDF & No & No & No & No & No & 5 \\
\hline DOC(X), RTF & No & No & No & No & No & 5 \\
\hline TXT & Yes & No & No & No & No & 5 \\
\hline HTML & Yes & Partial & No & No & No & 4 \\
\hline XLS(X) & No & Partial & No & No & No & 4 \\
\hline CSV & Yes & Yes & Partial & No & No & 3 \\
\hline JSON & Yes & Yes & Partial & No & No & 3 \\
\hline XML & Yes & Yes & Yes & No & No & 2 \\
\hline OData & Yes & Yes & Yes & Partial & Partial & 2 \\
\hline RDF & Yes & Yes & Yes & Yes & Yes & 1 \\
\hline
\end{tabular}

Source: Chlapek et al. (2012)

Table 2: Suitability of data format for publishing. 
on the format for classical JSON data. However, the most widespread format still remains the $\mathrm{XLS}(\mathrm{X})$, which is due to the global widespread of Microsoft products, including Windows operating system and office suite MS Office.

To determine the current state of availability of open data in agrarian sector 11 institutions that are major producers of agricultural data in the Czech Republic were selected. The evaluation took place in the first quarter of 2016 .

Analyzed departmental organization:

- Ministry of Agriculture (MA)

- $\quad$ State Agricultural Intervention Fund (SAIF)

- $\quad$ State Land Office (SLO)

- Czech Agriculture and Food Inspection Authority (CZAFIA)

- Institute of Agricultural Economics and Information (IAEI)

- Central Institute for Supervising and Testing in Agriculture (CISTA)

- State Veterinary Administration (SVA)

- $\quad$ Czech Forests, state enterprise (CZF)

- Czech Agrarian Chamber (CZACH)

- Federation of the Food and Drink Industries of the Czech Republic (FFDICZ)

- $\quad$ Czech Statistical Office (CZSO).

An example of the evaluation process

Method of description and assessment of the data availability from individual organizations is shown on example of the State Agricultural Intervention Fund:

SAIF is an entity that is involved in supporting the management of Czech farmers. It is an accredited paying agency, which is responsible for mediating financial support from the EU and national sources (State Agricultural Intervention Fund).

SAIF is responsible for the following payments (State Agricultural Intervention Fund):

- $\quad$ Direct payments (DP)

- Rural Development Programme (RDP) 20072013 / 2014-2020

- The Common Market Organisation (CMO)

- vegetal commodities

- animal commodities

- foreign trade

- Operative Programme Fisheries (OPF) 2007-2013 / 2014-2020
- National subsidies

- Quality food brands KLASA and Regional Food.

SAIF collects data from farmers mainly through LPIS (Land Parcel Identification System). A larger portion of data that SAIF analyzes and controls through LPIS has sensitive and personal nature. It is mainly data on the applications for grants of specific individuals, which also contain sensitive personal data. Information on subsidies that are tied to a particular plot is not in the public part of LPIS. It is accessible only after login and only for that plots' owner.

Data published by SAIF:

\begin{tabular}{|c|c|c|c|}
\hline $\begin{array}{c}\text { Available } \\
\text { data }\end{array}$ & Content & Format (export) & $\begin{array}{c}\text { Degree } \\
\text { of openness } \\
(1 \text { to } 5)^{*}\end{array}$ \\
\hline $\begin{array}{l}\text { List } \\
\text { of subsidy } \\
\text { recipients }\end{array}$ & $\begin{array}{ll}- & \text { Name (company } \\
\text { - } & \text { registration number) } \\
\text { Total amount } \\
\text { received in CZK } \\
\text { List of subsidy } \\
\text { programmes } \\
\text { of applicant } \\
\text { Ratio of Czech to EU } \\
\text { subsidies }\end{array}$ & Web application & N/A \\
\hline $\begin{array}{l}\text { Market } \\
\text { Information } \\
\text { System }\end{array}$ & $\begin{array}{ll}\text { - } & \text { Market reports } \\
\text { - } & \text { Pricing service }\end{array}$ & PDF & 1 \\
\hline $\begin{array}{l}\text { Regional } \\
\text { Food } \\
\text { Product }\end{array}$ & $\begin{array}{ll}\text { - } & \text { Registry of products } \\
\text { - } & \text { Recepies } \\
\text { - } & \text { Methodics for } \\
& \text { applications } \\
\text { - } & \text { Applications } \\
\text { - } & \text { Etc. }\end{array}$ & Web application & N/A \\
\hline $\begin{array}{l}\text { Law } \\
\text { no. } 106\end{array}$ & - Upon request & $\begin{array}{l}\text { PDF, XLS, } \\
\text { (ZIP) }\end{array}$ & $1-2$ \\
\hline
\end{tabular}

Source: State Agricultural Intervention Fund, List of subsidy receivers, Regional food product

Table 3: Data published by SAIF.

SAIF portal publishes a list of subsidy recipients including the amount paid from the preceding year (Figure 1).

Names of individual recipients refer to a different table, in which the year, fund or support type - purpose of subsidy, resources given by Czech Republic, by EU and a total subsidy amount in CZK are displayed.

A list of subsidy recipients is published in accordance to the Act no. 106/1999 Coll. The listing has however only informative character. Therefore, there is no possibility of its further use for various analyzes and processing. Data is not possible to download or further publish. So in this sense, it is not open data. The data provided has limited information value since surveys of who achieved what amount of subsidy has scant relevance. However, if the fund opened up the data 


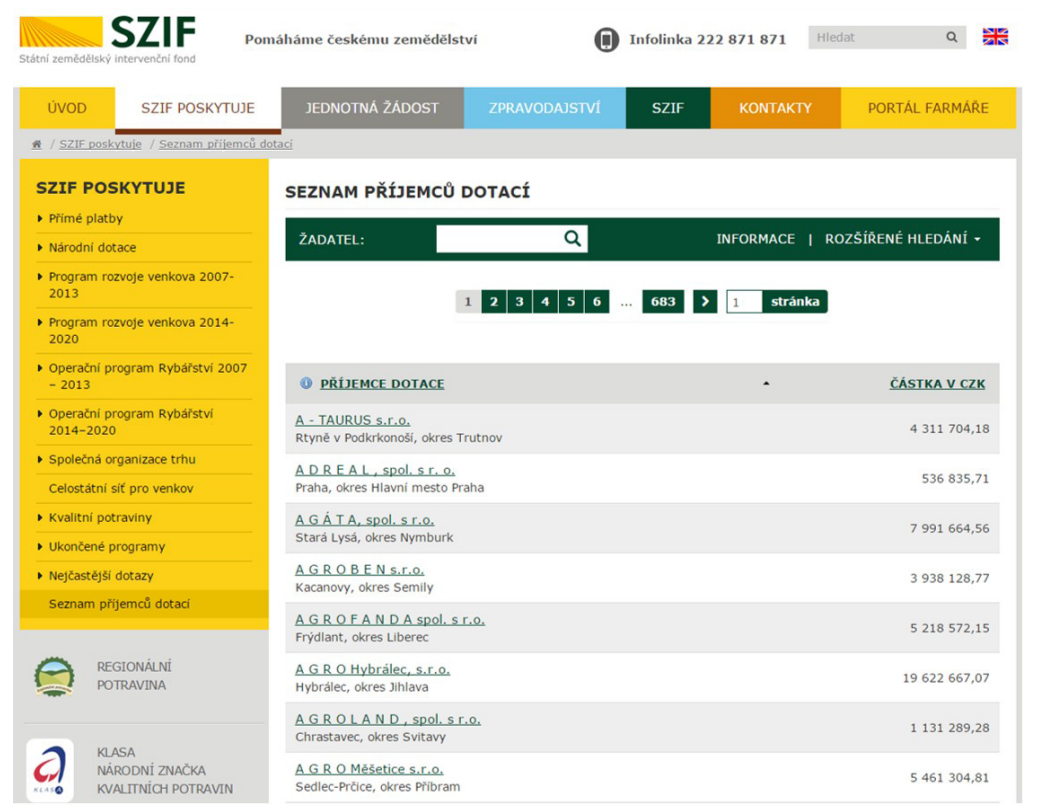

Source: List of subsidy recipients

Figure 1: List of subsidy recipients shown on SAIF portal.

and allowed them to be further processed, its value would increase tremendously. The result would be the option to create a variety of applications above the data, which could bring insight into the management of the fund to the general public and facilitate the data visualization.

On the basis of law no. 106 SAIF provides other data as well. Some of them are in a format that allows further processing or other use (XLS). The problem lies in the fact that this data must be formally requested, which is a significant obstacle to its immediate use. So again, we can call this an open data. This data can be requested from SAIF by mail, electronically (email) via data box or in person at the office registry. Anyone can ask for any data that does not collide with the Law on Protection of Personal Data. However, as far as state and EU finances are concerned there is only small amount of data that would be protected by this law, because a rule of transparency applies in this situation.

Among other information the fund discloses are information from a market information system. This system delivers current news from the market for agricultural products. The fund regularly publishes monthly newsletters reporting on agricultural commodity markets in the Czech Republic, European Union and other countries.

The portal publishes market reports on these commodities, products or programs (Market Information System):
- Potatoes

- Poultry

- Beef and pork

- Grains and oilseeds

- Fruits

- Rural Development Programs

- Wine and grapes

- Vegetables.

Another part of the market information system is a pricing service. There are regularly published pricing reports for individual agricultural commodities and products, which Czech Republic is required to watch according to the European legislation and send the reports to the European Commission.

The pricing service gives reports for these commodities (Market Information System):

- Bananas

- Dairy products

- Cereals

- Fruits and vegetables

- $\quad$ Pigs and piglets

- Cattle

- Eggs and poultry

- Wine.

All documents are published in the form of monthly reports. They contain relatively detailed 
information about the commodity, including lots of tabular data, charts, comparisons, comments and analyses results. Published reports have really high informational value and are surely finding frequent application. That is why they are issued with such regularity and quality. The only downside is the fact that all published documents are in PDF format, so the machine readability is very low. This unfortunately devaluates all published data significantly. If the fund began to publish these as open data, it would mean a lot of opportunities for their further use. Given that these data can be used in both commercial and personal sectors in wide range of applications, the public would certainly welcome opening up this data.

\section{Results and discussion}

The following table provides a clear representation of the results of the analysis of availability of open data and information in the agrarian sector.

Table 4 shows that the development regarding open data in the agrarian sector is not at very high level and is considerably worse than in other sectors. Most institutions do not publish open data at all, and if so, it is not an open data with a sufficient degree of openness.

Data which is publicly accessible on the institution portals has generally no restrictions on its subsequent use, so it is possible to consider such data to be at least partially open.

MA has undertaken the biggest step towards open data at the end of last year when it published a substantial GIS part of the LPIS portal that was not publicly available before. Here it is necessary to particularly highlight the fact that the data from the LPIS portal can be exported into open XML format. MA was followed by other institutions such as the SVA or CISTA. Here it should be noted that many other data remain internal. Among them one could find a lot of other data that could be potentially made open. Most of the already published data has great potential in their subsequent use. There are options for potential developers and for the general public. Developers will mainly appreciate access to data in "raw" format. The biggest area opened for specialized farming applications - pest occurrence registers, advisor registers, catalogs of public commissions, etc. On the other hand, the Ministry of Agriculture and other institutions took patronage over of these applications themselves. These applications, which transform the "raw data" to other forms of information, find their use mostly with the general public (Charvat et al., 2014).

However, a problem occurs with institutions that have chosen to disclose only the fully ready information, not "raw data". Many of these

\begin{tabular}{|c|c|c|c|c|c|c|}
\hline Institution & $\begin{array}{c}\text { Publishes } \\
\text { data }\end{array}$ & $\begin{array}{c}\text { Data } \\
\text { formats }\end{array}$ & $\begin{array}{c}\text { Achieved degrees } \\
\text { of openness* }\end{array}$ & $\begin{array}{c}\text { Open information } \\
-\mathrm{PDF}^{* *}\end{array}$ & Limits & $\begin{array}{c}\text { Information } \\
\text { value }\end{array}$ \\
\hline MA & yes & XML, XLS & $0-3$ & yes & $\begin{array}{l}\text { only selected } \\
\text { data - mainly } \\
\text { from LPIS }\end{array}$ & high \\
\hline SAIF & no & - & $0-1$ & yes & $\begin{array}{l}\text { possibility } \\
\text { of fees }\end{array}$ & medium \\
\hline SLO & no & - & 1 & yes & none & low \\
\hline CZAFIA & no & - & - & yes & none & high \\
\hline IAEI & no & - & - & yes & $\begin{array}{l}\text { possibility } \\
\text { of fees }\end{array}$ & medium \\
\hline CISTA & yes & XLS, CSV & $0-2$ & yes & none & high \\
\hline SVA & yes & XLS & $0-2$ & yes & none & high \\
\hline $\mathrm{CZF}$ & no & - & $0-1$ & yes & fees & medium \\
\hline $\mathrm{CZACH}$ & no & - & - & $\begin{array}{c}\text { no - only activity } \\
\text { reports }\end{array}$ & none & low \\
\hline FFDICZ & no & - & $0-1$ & yes & none & high \\
\hline CZSO & yes & XLS & $1-2$ & yes & $\begin{array}{l}\text { restrictions } \\
\text { defined by } \\
\text { CZSO apply }\end{array}$ & high \\
\hline
\end{tabular}

Note: * Based on the five-star rating, individually requested data not included

**Law no. 106/1999 Coll., and other documents not further processed

Source: own processing 
"national" applications are indeed good, but lack a space for developers who could bring new ideas through their own applications, and possibly further enrich such data (Jarolimek et al., 2014) (Reznik et al., 2015). But it can not be said that a state institution always equals the best solution. The above-mentioned applications will surely have their use in the future. For example, the web application "Food at the stake", which was formed under the leadership CZAFIA and already won numerous evaluations. Another application with great future potential is "Find your own producer" by FFDICZ, but it is still in the early stages of development and integration. Another high-quality concept is a SAIF portal "Regional food," which offers consumers high quality and comprehensive information regarding this brand and how it is being awarded.

Regarding the situation with open data in the agrarian sector, CZSO can be considered as the largest distributor of "raw data". Data published CZSO are clear, electronically readable, properly described and should be an example for all other institutions. It is possible to say that its potential for further use in the agrarian sector is really more than sufficient. But it is also necessary to mention that when using open data it is still a requirement to refer to the original source. The openness of data lies in the possibility of unlimited use anywhere, by anyone and for any purpose. All data published by CZSO is in machine-readable formats have a high degree of standardization.

Final evaluation is as follows: data is published only by 3 out of 11 surveyed institutions, one of which (CZSO) does not directly belong to the agrarian sector. These results can be assessed as slightly less than average. Highest quality data is published by the Ministry of Agriculture itself, since valuable exports from the portal LPIS are available in an open XML format that allows unlimited other usage, which is confirmed by the authorization of the free disposal of available data directly on eAGRI portal. Quality of other published data falls into the category of two stars, where its subsequent use is predetermined by owning specialized (often commercial) applications. Regarding the data publishing itself, the situation has somewhat improved. Information released thanks to the Act no. 106/1999 Coll. is provided by almost all institutions with the exception of CZF. The problem may be the possibility of charging for this service, which of course raises numerous discussions regarding the freedom of access to information. Some institutions also publish other free information on their own portals, usually about their activities. This information is in most cases available in PDF. This format does not allow further processing of information, which can greatly reduce the information value of the data. An example of good practice is the Market Information System portal by SAIF, which provides a very carefully crafted data that could be used and processed in other fields such as econometrics and forecasting.

\section{Data standardization}

One of the functions of open data should be the possibility of linking with other datasets. This feature can greatly increase the informational value of the final dataset (Sieber and Johnson, 2015). However, none of the examined data supports this. Although most of the formats are readable and usable for a wide range of users, it is still mainly XLS formats. To fully utilize the data in this format, one must have a commercial software MS Excel. These facts unfortunately do not correspond with open data policies in the true sense of the word, but at least some effort has been made towards openness.

A bigger problem occurs with the standardization of thes datasets. According to the results of analysis in the Czech agrarian sector we can not talk about any standardization whatsoever. Data is diverse, often unsorted and in various formats. The problem may also be in the use of graphic elements, for example coloring of cells, usage of variety of fonts etc. This problem stems from the fact that the datasets are compiled by different people from different institutions or external companies. The greatest degree of standardization dataset exists within the CZSO, but without additional export to other formats this still does not allow for linking to other datasets (therefore a five-star rating is currently infeasable).

The data published is also lacking consistency (Figure 2). As an example, a list of subsidy recipients from the SAIF portal was compared to register of subsidy recipients from eAGRI portal. This should be an absolutely identical lists of individuals and legal entities. Both institutions are also interconnected. Their connection is (in terms of subsidy administration) of the utmost importance with respect to other institutions under the Ministry of Agriculture. Both lists are, however, upon closer inspection quite different. They evaluate exactly the same subsidy programs, but the final values are considerably different. This fact is mainly 


\section{SEZNAM PŘÍJEMCŮ DOTACÍ}

\begin{tabular}{|c|c|c|c|c|c|}
\hline \multicolumn{2}{|c|}{ ROSTĚNICE,A.S } & & & & \\
\hline \multicolumn{6}{|c|}{ Rostěnice-Zvonovice, okres Vyškov } \\
\hline ROK & $\begin{array}{l}\text { FOND/TYP } \\
\text { PODPORY }\end{array}$ & OPATŘENI & ZDROJE ČR & ZDROJE EU & CELKEM CZK \\
\hline 2014 & EZFRV & $\begin{array}{l}\text { I.1.3.1.c-Pr̆idáváni hodnoty } \\
\text { zemédélským a } \\
\text { potravinárským produktům } \\
\text { územi mimo hlavniho města } \\
\text { Prahy }\end{array}$ & 64500,00 & 193500,00 & 258000,00 \\
\hline 2014 & EZFRV $14+$ & $\begin{array}{l}\text { Agroenvironmentáni opatřeni } \\
2007-13\end{array}$ & 8696,70 & 26090,03 & 34786,73 \\
\hline 2014 & EZZF PP & Platba na plochu & 0,00 & 47522255,46 & 47522255,46 \\
\hline 2014 & EZZF PP & Oddēlená platba za cukr & 0,00 & 13632977,85 & 13632977,85 \\
\hline
\end{tabular}

Základní evidované údaje o hospodaření

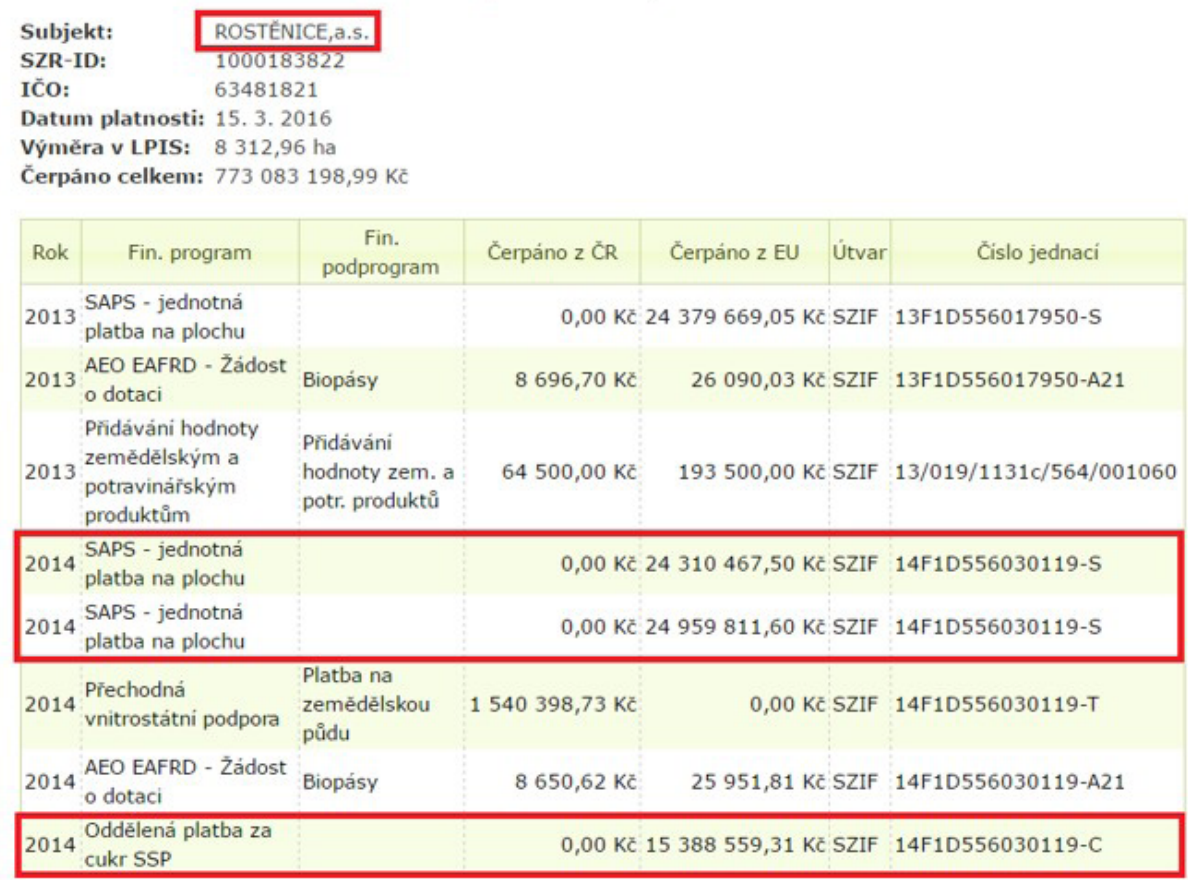

Source: List of subsidy recipients, Czech Ministry of Agriculture

Figure 2: Example of data inconsistencies between SAIF and MA.

due to absence of many records at eAGRI portal. The list compiled by SAIF can be therefore considered as more credible source of information. With such a large degree of mutual integration of both institutions this situation cannot be described as anything but very irregular.

Problems of this kind are not only between institutions, but also within a single institution, for example, the Ministry of Agriculture. The problem is especially noticeable when you export data from different applications, where the resulting structure of the exported file often differs. This example shows that the level of data standardization of this institution is very low.

\section{Conclusion}

The analysis showed that the current situation with open data in the agrarian sector is not optimal. Data formats that allow further processing are published by only two out of ten analyzed departmental organizations. A similar situation prevails in the National Catalog of Open Data where no data is coming from the agricultural sector. 
The overall amount of content in the National Catalog is still very low. Data in further processable format are only published by MA and SVA on their portals. Ministry of Agriculture contributed towards the disclosure of data in December last year by publishing of significant portion of the geographic LPIS portal from which it is possible to export data to XML. XML format is multiplatform and therefore offers the possibility of further processing. There are also various data available from different registers, which is predominantly in XLS format. The portal, where data are available usually imposes no limitations for working with such data. Hence we can consider this essentially as open data, although not published as such. Another institution that contributes to a significant degree of disclosure of data in the agrarian sector is CZSO. Although this office is not an organization directly from agrarian sector, it publishes high-quality statistical data from the agriculture, food industry and forestry, all of which are significant branches of the agrarian sector. Use of such data is limited by the terms of the statistical office and therefore it is not open data per say. Data from CZSO are very clear, well structured and above all has a high degree of standardization.

That is the biggest problem of all previously released data across institutions in this sector. Standardization is not only an inter-institutional problem but also within the institutions themselves, see also (Juell-Skielse et al., 2014). An example of incorrect standardization is MA itself, where they use different data formats or even different structure. Even before the individual institutions decide to open up the data in RDF format, it is necessary to deal with standardization. The most appropriate format for the initial publication is XML. Until all the data is published in open XML formats with a clear structure it is not possible to even contemplate publication of linked data in RDF format. It offers the possibility to link with other databases, whether on a national or a world scale. The result is enriched data with a high degree of standardization and increased value of information that can be used for further processing or for developing a variety of applications.

Information in various forms is provided by all of the analyzed institutions. They most commonly publish information in PDF format. This format is also frequently associated with the responces to requests for free access to information. Additional information is provided to end consumers through a special web portals or other available documents. The data provided has different levels of information value. In particular, portals dedicated to food, which provide very useful information about food to final consumers, exhibit the highest levels of data quality and information value. However, usefulness of some of this data for further processing is lowered by used data format. This in particular applies to the Market Information System by SAIF, where the monthly reports with high quality data are only available in PDF.

Because the data is published by small number of institutions it is necessary to focus on the correct procedure for its eventual publication. It includes the following steps:

1. Selection of appropriate data

2. Standardization

3. Selection of the place and manner of publication

4. Evaluation of the potential benefit of publications.

The most important step is to standardize, which brings some order to all data published in the agrarian sector. Standardization nowadays also does not impose excessive financial and technical difficulty. When selecting the appropriate data, the farming data sensitivity must be taken into account. The third step depends on the arrangement between individual institutions, whether they prefer a centralized or decentralized manner of publishing and what form of visualization they decide upon - maps, web applications, spreadsheets, etc. (Kubicek et al., 2013; Ojha et al., 2015).

\section{Acknowledgements}

The results and knowledge included herein have been obtained owing to support from the Internal grant agency of the Faculty of Economics and Management, Czech University of Life Sciences in Prague, grant no. 20161028, “Assessment of quality, usability and accessibility of electronic services from the perspective of small and middle sized enterprises in the agrarian sector ". 
Corresponding author:

Ing. Jan Jarolimek, Ph.D.

Department of Information Technologies, Faculty of Economics and Management Czech University of Life

Sciences Prague, Kamýcká 129, Prague 6 - Suchdol, 165 21, Czech Republic

Phone: +420 22438 2293, E-mail: jarolimek@pef.czu.cz

\section{References}

[1] Atenas, J., Havemann, L. and Priego, E. (2015) „Open Data as Open Educational Resources: Towards transversal skills and global citizenship", Open praxis, Vol. 7, No. 4, pp. 377-389. ISSN 2304-070X. DOI 10.5944/openpraxis.7.4.233.

[2] Bellon-Maurel, V., Peters, G. M., Clermidy, S., Frizarin, G., Sinfort, C., Ojede, H., Roux, P. and Short, M. D. (2015) „Streamlining life cycle inventory data generation in agriculture using traceability data and information and communication technologies-part II: application to viticulture", Journal of cleaner production, Vol. 87, pp. 119-129. ISSN 0959-6526.

[3] Czech Republic (1999) Law no. 106/1999 Coll. dated May $11^{\text {th }} 1999$ on free access to information. Czech Republic legislation, 1999. ISSN 1211-1244.

[4] European Parliament and Council (2013) European Parliament and Council Directive 2013/37/EU, June $26^{\text {th }} 2013$.

[5] Gymrek, M. and Farjoun, Y. (2016) „Recommendations for open data science”, Gigascience. Vol. 5. ISSN 2047-217X. DOI 10.1186/s13742-016-0127-4.

[6] Hausenblas, M. (2012) 5-star Open Data. 22 Jan. 2012. [Online]. Available: http://5stardata.info/en/. [Accessed: 10 Oct. 2015].

[7] Holster, H., Fusai, B., Giannerini, G., Horakova, S., Martini, D., Teye, F., and Ipema, B. (2011) „Current situation on data exchange in agriculture in the EU27 \& Switzerland”, EFITA/WCCA '11. pp. 367-381. ISBN 978-80-904830-0-2.

[8] Hossain, M. A., Dwivedi, Y. K. and Rana, N. P. (2016) „,State-of-the-art in open data research: Insights from existing literature and a research agenda", Journal of organizational computing and electronic commerce, Vol. 26, No. 4, pp. 14-40. ISSN 1091-9392. DOI 10.1080/10919392.2015.1124007.

[9] Charvat, K., Esbri, M., Mayer, W., Campos, A., Palma, R. and Krivanek, Z. (2014) „FOODIE - Open data for agriculture“. 2014 IST-Africa Conference Proceedings. [Online]. Available: https://scholar. google.czscholar?q=FOODIE $+\%$ E2\%80\%94+Open + data + for + agriculture $\& b t n G=\& h l=c s \& a s$ $\mathrm{sdt}=0 \% 2 \mathrm{C} 5$. [Accessed: 13 Aug. 2016]. ISBN 978-1-905824-44-1. DOI 10.1109/ISTAFRICA.2014.6880647.

[10] Chlapek, D., Kucera, J. and Necasky, M. (2012) „Metodika publikace otevřených dat veřejné správy ČR.“ (In Czech). [Online]. Available: http://www.korupce.cz/assets/dokumenty/aktuality/Metodikapublikace-otevrenych-dat.pdf. [Accessed: 20 Nov. 2015].

[11] Janssen, M., Charalabidis, Y. and Zuiderwijk, A. (2012) „Benefits, Adoption Barriers and Myths of Open Data and Open Government", Information systems management, Vol. 29, No. 4, pp. 258-268. ISSN 1058-0530. DOI 10.1080/10580530.2012.716740.

[12] Jarolimek, J., Vanek, J., Jezek, M., Masner, J. and Stoces, M. (2014) „The telemetric tracking of wild boar as a tool for field crops damage limitation“, Plant, Soil and Environment, Vol. 60, No. 4, pp. 418-425. ISSN 1214-9368.

[13] Juell-Skielse, G., Hjalmarsson, A., Johannesson, P. and Rudmark, D. (2014) „Is the Public Motivated to Engage in Open Data Innovation?", Electronic government (EGOV 2014), Vol. 8653, pp. 277-288. ISSN 0302-9743. DOI 10.1007/978-3-662-44426-9_23.

[14] Kubatova, E. and Faugnerova (2015) INSPIRE. Infrasructure for Spatial Information in Europe. [Accessed: 11 Nov. 2015]. Available: http://inspire.gov.cz/o-inspire. 
[15] Kubicek, P., Kozel, J., Stampach and R., Lukas, V. (2013) „Prototyping the visualization of geographic and sensor data for agriculture”, Computers and electronics in agriculture, Vol. 97, pp. 83-91. ISSN 0168-1699.

[16] Lassinantti, J., Bergvall-Kareborn, B. and Stahlbrost, A. (2014) „Shaping Local Open Data Initiatives: Politics and Implications", Journal of theoretical and applied electronic commerce research, Vol. 9, No. 2, pp. 17-33. ISSN 0718-1876. DOI 10.4067/S0718-18762014000200003.

[17] Ministry of Interior (2015) „Školení otevřených dat VS ČR“. [Online]. Available: http://opendata. gov.cz/_media/edu:skoleni_open_data_web.pdf. [Accessed: 10 Oct. 2015].

[18] Czech Ministry of Agriculture (2016) „Registry of subsidy recipients“. [Online]. Available: http://eagri.cz/public/app/SZR/SubsidyReports\#filter--Subjid=\&Ico=\&SzifId=\&LpisId=\&Rci=\&D atNaroz $=\& O b c h J m=\& J m e n o=\&$ Prijmeni $=\& O b e c N a z=\&$ ObecKod $=\&$ Ulice $=\& O k r e s=\&$ searched $=$ Reload. [Accessed: 20 Feb. 2016].

[19] Ojha, S. R., Jovanovic, M. and Giunchiglia, F. (2015) „Entity-Centric Visualization of Open Data”, Human-Computer interaction - Interact 2015, PT III, Vol. 9298, pp. 149-166. ISSN 0302-9743. DOI 10.1007/978-3-319-22698-9_11.

[20] Open Knowledge (2015) „Global Open Data Index“. [Online]. Available: http://index.okfn.org/ place/czech-republic/2014/. [Accessed: 29 Nov 2015].

[21] Reznik, T., Charvat, K. Jr., Charvat, K., Horakova, S., Lukas, V. and Kepka, M. (2015) „Open Data Model for (Precision) Agriculture Applications and Agricultural Pollution Monitoring”, Proceeding of envroinfo and ict for sustainability 2015, Vol. 22, pp. 97-107. ISSN 2352-538X. DOI 10.2991/ict4s-env-15.2015.12.

[22] Sieber, R. E., Johnson, P. A. (2015) „Civic open data at a crossroads: Dominant models and current challenges", Government information quarterly, Vol. 32, No. 3, pp. 308-315. ISSN 0740-624X.

[23] State Agricultural Intervention Fund (2015) „O nás“. [Online]. Available: https://www.szif.cz/cs/onas. [Accessed: 20 Dec. 2015].

[24] List of subsidy recipients (2016). [Online] Available: https://www.szif.cz/cs/seznam-prijemcudotaci. [Accessed: 10 Feb. 2016].

[25] Regionální potravina. [Online]. Available: http://www.regionalnipotravina.cz/. [Accessed: 10 Feb. 2016].

[26] Stočes, M., Benda, P. and Ulman, M. (2015) „Open data and rural development. In: Agrarian Perspectives XXIV. - Global Agribusiness and Rural Economy, 16.09.2015, Prague. Czech University of Life Sciences Prague, pp. 399-406. ISBN 978-80-213-2581-4, E-ISSN 2464-4781, ISSN 1213-7960.

[27] Market Information System (2016). [Online]. Available: https://www.szif.cz/cs/trzni-informacnisystem. [Accessed: 24 Feb. 2016].

[28] Thorp, K. R., Bronson, K. F. (2013),AA model-independent open-source geospatial tool for managing point-based environmental model simulations at multiple spatial locations", Environmental modelling \& software, Vol. 50, pp. 25-36. ISSN 1364-8152.

[29] Vanek, J., Kanska, E., Jarolimek, J. and Simek, P. (2010) „State and evaluation of information and communication technologies development in agricultural enterprises in Czech Republic“, Plant, Soil and Environment, Vol. 56, No. 3, pp. 144-147. ISSN 1214-1178.

[30] Zuiderwijk, A., Janssen, M. and Dwivedi, Y. K. (2015) „Acceptance and use predictors of open data technologies: Drawing upon the unified theory of acceptance and use of technology", Government information quarterly, Vol. 32, No. 4, pp. 429-440. ISSN 0740-624X 